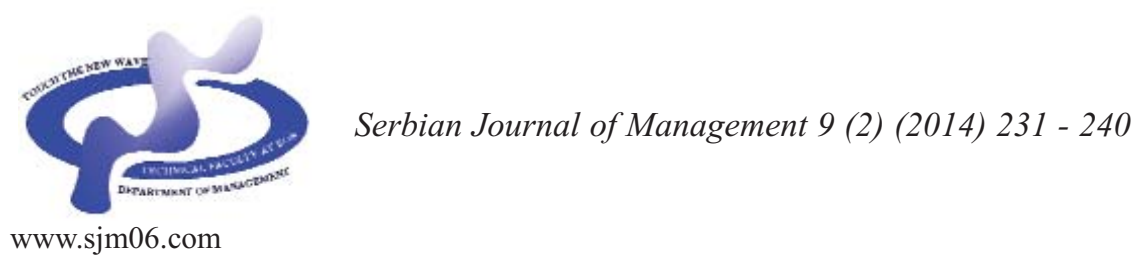

Serbian

Journal of

Management

\title{
BAYESIAN INFERENCE FOR RISK ASSESMENT OF THE POSITION OF STUDY PROGRAM WITHIN THE INTEGRATED UNIVERSITY: A CASE STUDY OF ENGINEERING MANAGEMENT AT TECHNICAL FACULTY IN BOR
}

\author{
Marija Savić*, Predrag Đorđević, Đorđe Nikolić, Ivan Mihajlović and Živan Živković \\ University of Belgrade, Technical Faculty in Bor, Serbia
}

(Received 10 June 2014; accepted 23 July 2014)

\begin{abstract}
This paper defines issues involved with the Integrated University (IU) from the aspect of the positioning of study program (SP) as the basic component of modern IU. Model for the risk assesment of the SP position in IU is developed on the principles of Bayes' theorem of conditional probability. In the proposed model, a priori probability is updated with previous events (evidence nodes) ei, whose occurrence caused a final posterior probability of the position of SP in IU. Defined model was developed based on the example of SP - Engineering management (EM) within the Technical Faculty in Bor, in order to assess the probability of its position in the future IU in Belgrade. The results show that SP-EM has a probability above $99 \%$ with its current structure and new activities, to be a part of the IUB. Defined model has a universal character and can be applied to analyze the posterior probability of any SP's position and risk assesment with the variation of the number and content of the evidence nodes $\mathrm{e}_{i}$.
\end{abstract}

Keywords: Bayes, Integrated University, model, probability, study program

\section{INTRODUCTION}

Ranking of the Universities in the world (Academic Ranking World Universities ARWU conducted by Shanghai University "Cao Tun", since 2003) has special

* Corresponding author: msavic@tf.bor.ac.rs

DOI:10.5937/sjm9-6391 significance today, especially for the universities, because it increases their reputation in the world and puts them in a better position for getting major projects and attracting students from all over the world (Florian, 2007). The most prestigious, so 
called Shanghai list of the top 500 universities in the world (about $2 \%$ of the total universities in the world) is formed on the basis of scientific results published in SCI journals, generated citations, the volume of international cooperation, the scope of the alumni, and other elements of the Universities' impact on society and the region in which it is operating (Cooper, 2007; Sando \& Ferenčak, 2012).

In the modern concept of Integrated University (IU), in which the ponderous faculties lose their status, Departments Study programs (SP) are directly joining in the IU, and based on the achieved results, receive authority to grant $\mathrm{PhD}$ degrees and become carriers of certain scientific discipline (SD) in the University (EU Directive, 2013). Universities and SP's are being recognized and create conditions for achieving positions of top 500 or top 100 , and the very best among them are trying to place in the top 10 (for example: Harvard, Stanford, Berkeley, MIT, Cambridge, Caltech, Princeton, Columbia, Chicago, Oxford). Graduates of the most prestigious universities are recognized by the SP within their university, which they graduated from. For example, Harvard has been holding the number one position for more than a decade and in its long history it educated eight U.S. presidents and 48 Nobel Prize winners (Florian, 2007).

In order to achieve mentioned quality (Khan \& Adil, 2013) which is represented by performance of the SP, a necessary condition is to have developed scientific research as a fundamental prerequisite for high-quality teaching activities. The departments should be recognized by a research direction which is globally current (in at least a few areas in which best practice is fostered, either by using new directions or creating new approaches of their own), by publication of the papers in the journals with high impact factor (IF) and presenting them at the relevant scientific conferences (Florian, 2007). In this way, many departments and SP's become recognized by a discipline, which is in the best sort of recommendation for them to perspective students from all over the world, especially at the master's and doctoral level of studies (Huang, 2012).

Non-integrated University of Belgrade (UB) - Serbia works with 33 different faculties employing 3,000 teachers and where 310 SP's is implemented with approximately 85,000 students, and it has been placed among the top 500 universities in the world for the last two years. Examples of non-integrated universities (NIU) can be seen in other post-communist countries in transition, beside Serbia, which is in contradiction with the European Union Standards (EU Directive, 2013). These facts suggest that these NIU, as well as the UB, will undergo a radical transformation in the future and become IU which will essentially be consisted of SP's and not the faculties.

The process of transition of UB into the IU requires many efforts in changing perception in understanding how IU functions, which is not adequate in the UB at a present moment. Technical Faculty in Bor (TFB) has been functioning as a part of BU since 1961 (it is the only faculty which is not situated in Belgrade) and has four SP's: Mining Engineering (MI), Metallurgical Engineering (METI), Technological Engineering (TI) and Engineering Management (EM). The problem of the TFB in the process of transformation of $\mathrm{BU}$ into IU is a complex one, if the fact is taken into account that three out of four SP's (MI, METI and TI) are being realized in parallel with other faculties at BU. The risk which is 
recognized in this case is reflected within the fact that some of the SP's, which are realized at the TFB will not become a part of the IUB, which means losing affiliation with top 500 for TFB, which can further cause large losses for these SP's and the whole TFB (Khan \& Adil, 2013).

There is an attitude at TFB which represents a bad school of thought in the University, recurring from the communist ideology, that huge teams should be assembled with people from all departments - SP's, in which "the good ones drag the bad ones - our comrades" and thus create a "collective" good results. This opinion is widespread among professors who are admitted to the University as a result of negative selection of personnel. The motivation of these professors to work at the University is achieving only the first two levels of Maslow's hierarchy of needs and motives (decent wages and job security) (Maslow, 1943). These teachers usually count the years until their retirement, protecting them shelf with the non reelection clause for full professors, behavior which in no way embodies the professors at the modern IU, especially not those from the group of top 500 .

In this paper an attempt is made to asses the risk and determine the position of the SPEM within the future IUB. The motivation for this study also lies in the fact that three out the four SP's: MI, METI and TI (with a tradition of over 50 years) have being implemented for a much longer period of time in other Faculties of the BU than SP $\mathrm{EM}$, which is the unique to $\mathrm{BU}$, with a tradition of over 10 years. It is clear that the positioning in the IUB in the future requires above-average results.

\section{DEVELOPMENT OF THE THEORETICAL MODEL}

The outcome of this research is risk assessment of SP-EM entering from TFB within IUB, which is within the probability assessment. These outcome depends on past events which are also in the domain of certain probability. In order to define the model of the SP-EM within the TFB entering IUB in the future, the principles of Bayes' theorem of conditional probability were used (Bernardo \& Smith, 2000) $\mathrm{P}\left(\mathrm{A}_{\mathrm{i}} \mid \mathrm{B}\right)$ for $P(B)>0$, i.e.:

$P\left(A_{i} \backslash B\right)=\frac{P\left(A_{i}\right) P\left(B \backslash A_{i}\right)}{\sum_{i=1}^{n} P\left(A_{i}\right) P\left(B \backslash A_{i}\right)}$

where:

$\mathrm{P}(\mathrm{Ai})$ - probability of the outcome event; $\mathrm{P}(\mathrm{Ai} \backslash \mathrm{B})$ - probability of the outcome event $\mathrm{Ai}$ if the event $\mathrm{B}$ occurs prior to it (where $\mathrm{P}(\mathrm{B})>0)$.

In this case the statistical sample or the sample field Q is consisted of employees in all SP's i.e. departments at the TFB. Field sample $\mathrm{Q}$ is divided into four sets as follows: $\mathrm{A}-\mathrm{MI}$; B-METI; C-TI, D-EM, that is:

$\Omega=A \cup B \cup C \cup D$

Elements of sets A, B, C and D within the sample field $\Omega$ are:

Set A (MI): $a_{1}, a_{2}, a_{3}, \ldots, a_{n}$

Set B (METI): $b_{1}, b_{2}, b_{3}, \ldots, b_{n}$

Set C (TI): $c_{1}, c_{2}, c_{3}, \ldots, c_{n}$

Set D (EM): $d_{1}, d_{2}, d_{3}, \ldots, d_{n}$ 
that is:

$\Omega=A \cup B \cup C \cup D=\left\{a_{i}\left|a_{i} \in A, b_{i}\right| b_{i} \in B\right.$,

$\left.\mathrm{c}_{\mathrm{i}}\left|\mathrm{c}_{\mathrm{i}} \in \mathrm{C}, \mathrm{d}_{\mathrm{i}}\right| \mathrm{d}_{\mathrm{i}} \in \mathrm{D}\right\}$

The total number of elements in this case, in the sample field $\mathrm{Q}$ is:

$\Omega=\sum_{i=1}^{16} a_{i}+\sum_{i=1}^{16} b_{i}+\sum_{i=1}^{19} c_{i}+\sum_{i=1}^{29} d_{i}=80$

All elements of the sets A, B, C and D represent employees under their respective SP, with their personal qualities and characteristics and their results which affect the performance of individual SP. Bearing in mind that the position of each employee within the aforementioned SP's is achieved on the basis of the approximately same criteria on the BU, then the null hypothesis $\mathrm{H}_{0}$ can be defined as follows:

$H_{0}$ : All professors and teaching assistants, who are appointed to their position on the basis of approximately the same criteria, have the same opportunity to achieve results which are useful for the SP.

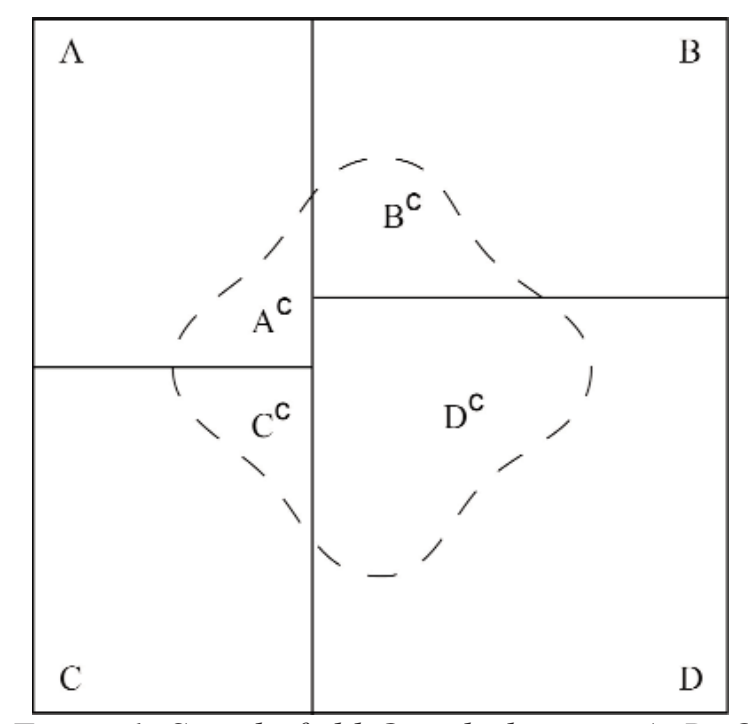

Figure 1. Sample field $\Omega$ with the sets: $A, B, C$ and $D(\Omega=A \cup B \cup C \cup D)$
Number of elements in each of these sets: $\mathrm{A}=\{16\} ; \mathrm{B}=\{16\} ; \mathrm{C}=\{19\}$ and $\mathrm{D}\{29\}$, will be the basis for calculating the elements of a priori probabilities for individual events in the considered sets. The Figure 1 schematically shows the sample field of considered sets, while taking into account the number of elements in the set.

Set size essentially does not have a predominant effect on the overall results achieved in the set - SP, because, despite the fact that all the elements have the same opportunities at the start, under the circumstances and because of the different levels of motivation for achieving higher levels of Maslow's scale of hierarchy of needs and motives (Maslow, 1943), contributions of the individual elements in such defined sets are different, that is:

$$
\begin{aligned}
& a_{1} \neq a_{2} \neq \ldots a_{16} \neq b_{1} \neq b_{2} \neq \ldots b_{16} \neq c_{1} \neq c_{2} \neq \ldots \\
& \ldots c_{19} \neq d_{1} \neq d_{2} \neq \ldots d_{29}
\end{aligned}
$$

Only a part of the elements within the defined sets account for achieving measurable results that define the position of the SP's, and they do this in different ways. This fact allows for this part of the elements within the same set, to be defined as its complement (Garvey, 2009):

$$
\begin{aligned}
& \mathrm{A}^{\mathrm{c}}=\left\{\exists \mathrm{a} \mid \mathrm{a}_{\mathrm{i}} \in \mathrm{A}\right\} ; \mathrm{B}^{\mathrm{c}}=\left\{\exists \mathrm{b} \mid \mathrm{b}_{\mathrm{i}} \in \mathrm{B}\right\} ; \mathrm{C}^{\mathrm{c}}= \\
& \left\{\exists \mathrm{c} \mid \mathrm{c}_{\mathrm{i}} \in \mathrm{C}\right\} ; \mathrm{Dc}=\left\{\exists \mathrm{d} \mid \mathrm{d}_{\mathrm{i}} \in \mathrm{D}\right\}
\end{aligned}
$$

Because of:

\urcorner$\left.\left.\left(\forall \mathrm{a}_{\mathrm{i}}\right) \in \mathrm{A}^{\mathrm{c}} ;\right\urcorner\left(\forall \mathrm{b}_{\mathrm{i}}\right) \in \mathrm{B}^{\mathrm{c}} ;\right\urcorner\left(\forall \mathrm{c}_{\mathrm{i}}\right) \in \mathrm{C}^{\mathrm{c}}$ and \urcorner$\left(\forall \mathrm{d}_{\mathrm{i}}\right) \in \mathrm{D}^{\mathrm{c}}$

then, $\mathrm{A}^{\mathrm{c}} \neq \mathrm{B}^{\mathrm{c}} \neq \mathrm{C}^{\mathrm{c}} \neq \mathrm{D}^{\mathrm{c}}$ 
therefore:

$$
\mathrm{A}^{\mathrm{c}} \cap \mathrm{B}^{\mathrm{c}} \cap \mathrm{C}^{\mathrm{c}} \cap \mathrm{D}^{\mathrm{c}}=\varnothing
$$

This proves that the "collective" positioning of several study programs within the IU is not possible. Thus, it follows that the risk assessment of the position of the each SP in the future IBU is mathematically more correct approach. It is therefore considered risk assessment for future position SP-EM in the future IUB, independent of the position of the other SP.

The main research hypothesis that defines the positioning of SP if one accepts the positivist "glass half full" approach is as follows:

$H_{1}$ : Department D or SP-EM will achieve a distinctive and leading position in the region, which will recommend them to become a part of the IUB.

A priori probability (Jaynes, 2003), for the assertion stated by the hypothesis $\mathrm{H}_{1}$ is:

$\mathrm{P}\left(\mathrm{H}_{1}\right)=0,5$

that is, SP-EM has the same a priori probability as another SP, to achieve a leadership role in the region and become part of the IUB, in other words:

$\mathrm{P}\left(\mathrm{H}_{1-\mathrm{A}}\right)=\mathrm{P}\left(\mathrm{H}_{1-\mathrm{B}}\right)=\mathrm{P}\left(\mathrm{H}_{1-\mathrm{C}}\right)=$ $\mathrm{P}\left(\mathrm{H}_{1-\mathrm{D}}\right)=0,5$

The contents of the work at University imposes the implementation of many tasks to the SP's, which can be considered as the previous events $\left(e_{i}\right)$ in the form of the observations that cause the $\mathrm{H}_{1}$ to occur. This situation is defined by the so-called conditional probability that incorporates information about the occurrence of other events (Garvey, 2009; O'Hagan \& West, 2010), that is:

$P\left(H_{1} \backslash e_{1}, e_{2}, \ldots . ., e_{n}\right)$

The main events preceding the achievement of the hypothesis $\mathrm{H}_{1}$, under the current working conditions at the non integrated University, can be defined as follows:

$\mathrm{e}_{1^{-}}$Progression of individuals and achieving above average results,

$\mathrm{e}_{2}$ - Commitment to students, the provision of textbooks, the number of students, transparency in the work etc.,

$\mathrm{e}_{3}$ - Conquering new scientific areas, publishing in journals with IF and acquiring more citations,

$\mathrm{e}_{4}$ - Taking care of the alumni,

$\mathrm{e}_{5}$ - Commitment to enhancing the general performance of SP and international cooperation.

Based on these views, Figure 2 shows a

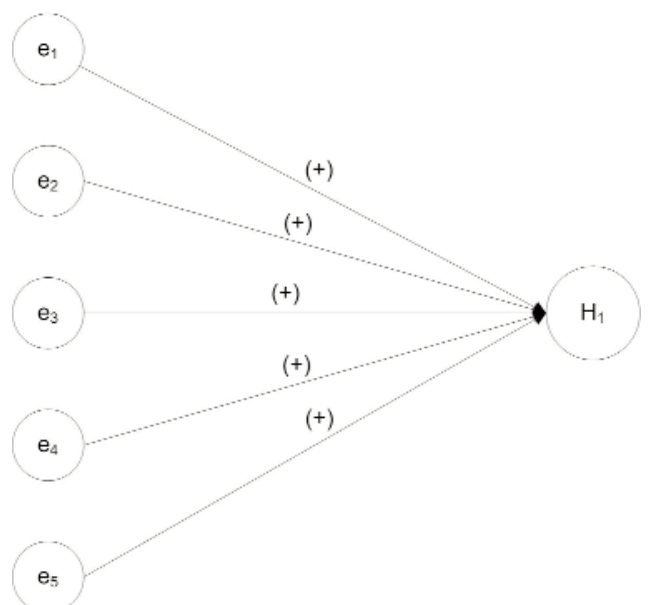

Figure 2. The theoretical model of the a posteriori probability for the realization of the hypothesis $\mathrm{Hl}_{1} \mathrm{e}_{1}, e_{2}, e_{3}, e_{4}, e_{5}$ 
theoretical model for the realization of the statement defined by equation (9), i.e. the realization of the hypothesis $\mathrm{H}_{1}$, updated by the events $e_{1}-e_{5}$ within the time intervals $t_{1}$ - $\mathrm{t}_{5}$, which presents an a posteriori probability (Shay \& Bakar, 2012) for the realization of the hypothesis $\mathrm{H}_{1}$.

In order to solve a problem of a posteriori probability of realization of the hypothesis $\mathrm{H} 1$ in the defined set D for SP-EM, the Bayes' theorem of conditional probability may be applied (Ordonez Galan et al., 2009; Chen \& Pollino, 2012; Shay \& Bakar, 2012), which for a given model is:

\section{DISCUSSION OF THE RESULTS}

A priori probability of realization of the hypothesis $\mathrm{H}_{1}$ in the defined set $\mathrm{D}$ is $\mathrm{P}\left(\mathrm{H}_{1}\right)=$ 0.5 . The other terms in equations (10.1)(10.5) are defined as follows: $\mathrm{P}\left(\mathrm{H}_{1} \backslash \mathrm{e}_{\mathrm{i}}\right)$ is the probability that $\mathrm{H}_{1}$ is true given the evidence $e_{i}$, the term $P\left(e_{i} \backslash H_{1}\right)$ is the probability that the evidence $e_{i}$ would be observed, given that $\mathrm{H}_{1}$ is true, and the term $\mathrm{P}\left(\mathrm{e}_{\mathrm{i}} \backslash \mathrm{H}_{1} \mathrm{c}\right)$ is the probability that the evidence $\mathrm{e}_{i}$ would be observed given that the $\mathrm{H}_{1}$ is not true (Garvey, 2009).

$$
\mathrm{P}\left(\mathrm{H}_{1} \backslash \mathrm{e}_{1}-\mathrm{e}_{5}\right)=\frac{\mathrm{P}\left(\mathrm{H}_{1} \backslash \mathrm{e}_{1}-\mathrm{e}_{5}\right) \mathrm{P}\left(\mathrm{e}_{1}-\mathrm{e}_{5} \backslash \mathrm{H}_{1}\right)}{\mathrm{P}\left(\mathrm{H}_{1} \backslash \mathrm{e}_{1}-\mathrm{e}_{5}\right) \mathrm{P}\left(\mathrm{e}_{1}-\mathrm{e}_{5} \backslash \mathrm{H}_{1}\right)+\left(1-\mathrm{P}\left(\mathrm{H}_{1} \backslash \mathrm{e}_{1}-\mathrm{e}_{5}\right)\right) \mathrm{P}\left(\mathrm{e}_{1}-\mathrm{e}_{5} \backslash \mathrm{H}_{1}^{\mathrm{c}}\right)}
$$

That is, by implementing step by step calculation:
According to Bayes' rule events $\mathrm{e}_{1}-\mathrm{e}_{5}$ (Figure 2) present the evidence node

$$
\begin{aligned}
& \mathrm{P}\left(\mathrm{H}_{1} \backslash \mathrm{e}_{1}\right)=\frac{\mathrm{P}\left(\mathrm{H}_{1}\right) \mathrm{P}\left(\mathrm{e}_{1} \backslash \mathrm{H}_{1}\right)}{\mathrm{P}\left(\mathrm{H}_{1}\right) \mathrm{P}\left(\mathrm{e}_{1} \backslash \mathrm{H}_{1}\right)+\left(1-\mathrm{P}\left(\mathrm{H}_{1}\right)\right) \mathrm{P}\left(\mathrm{e}_{1} \backslash \mathrm{H}_{1}^{\mathrm{c}}\right)} \\
& \text {. } \\
& \text {. } \\
& \mathrm{P}\left(\mathrm{H}_{1} \backslash \mathrm{e}_{1}, \mathrm{e}_{2}, \mathrm{e}_{3}, \mathrm{e}_{4}, \mathrm{e}_{5}\right)=\frac{\mathrm{P}\left(\mathrm{H}_{1} \backslash \mathrm{e}_{1}, \mathrm{e}_{2}, \mathrm{e}_{3}, \mathrm{e}_{4}\right) \mathrm{P}\left(\mathrm{e}_{5} \backslash \mathrm{H}_{1}\right)}{\mathrm{P}\left(\mathrm{H}_{1} \backslash \mathrm{e}_{1}, \mathrm{e}_{2}, \mathrm{e}_{3}, \mathrm{e}_{4}\right) \mathrm{P}\left(\mathrm{e}_{5} \backslash \mathrm{H}_{1}\right)+\left(1-\mathrm{P}\left(\mathrm{H}_{1} \backslash \mathrm{e}_{1}, \mathrm{e}_{2}, \mathrm{e}_{3}, \mathrm{e}_{4}\right)\right) \mathrm{P}\left(\mathrm{e}_{5} \backslash \mathrm{H}_{1}^{\mathrm{c}}\right)}
\end{aligned}
$$

where:

$$
\begin{aligned}
& \mathrm{P}\left(\mathrm{H}_{1} \backslash \mathrm{e}_{1}, \mathrm{e}_{2}\right) \equiv \mathrm{P}\left(\mathrm{H}_{1} \backslash \mathrm{e}_{1} \cap \mathrm{e}_{2}\right) ; \\
& \mathrm{P}\left(\mathrm{H}_{1} \backslash \mathrm{e}_{1}, \mathrm{e}_{2}, \mathrm{e}_{3}\right) \equiv \mathrm{P}\left(\mathrm{H}_{1} \backslash \mathrm{e}_{1} \cap \mathrm{e}_{2} \cap \mathrm{e}_{3}\right) ; \\
& \mathrm{P}\left(\mathrm{H}_{1} \backslash \mathrm{e}_{1}, \mathrm{e}_{2}, \mathrm{e}_{3}, \mathrm{e}_{4}\right) \equiv \mathrm{P}\left(\mathrm{H}_{1} \backslash \mathrm{e}_{1} \cap \mathrm{e}_{2} \cap \mathrm{e}_{3} \cap \mathrm{e}_{4}\right) ; \\
& \mathrm{P}\left(\mathrm{H}_{1} \backslash \mathrm{e}_{1}, \mathrm{e}_{2}, \mathrm{e}_{3}, \mathrm{e}_{4}, \mathrm{e}_{5}\right) \equiv \mathrm{P}\left(\mathrm{H}_{1} \backslash \mathrm{e}_{1} \cap \mathrm{e}_{2} \cap \mathrm{e}_{3} \cap \mathrm{e}_{4}\right. \\
& \left.\cap \mathrm{e}_{5}\right) .
\end{aligned}
$$

contributing to the truthfulness of $\mathrm{H}_{1}$. In the Bayesian inference community this is sometimes called updating (Anderson \& Vastag, 2004). That is, updating the "belief" in the truthfulness of a hypothesis in light of observations or evidence that adds new information to the initial or prior assessments (Kalina, 2014).

Based on the measurements and quantification of the results that elements $d_{i}$ achieve with their activities within the set $D$, 
i.e. the corresponding SP-EM, the realization of the hypothesis $\mathrm{H}_{1}$ for the probabilities $\mathrm{P}\left(\mathrm{e}_{\mathrm{i}} \backslash \mathrm{H}_{1}\right)$ and $\mathrm{P}\left(\mathrm{e}_{\mathrm{i}} \backslash \mathrm{H}_{1} \mathrm{c}\right)$ were assessed in a way that, for the events $\mathrm{e}_{1}, \mathrm{e}_{2}$ and $\mathrm{e}_{3}$, potentiality and the results achieved by individual elements of mentioned sets were taken into account. To assess the impact of $\mathrm{e}_{4}$ and $\mathrm{e}_{5}$, the achieved results measured relative to the results achieved by the best in the BU, are taken into account. The obtained results are shown in Table 1 . Given that the assessment of the probability $\mathrm{P}\left(\mathrm{e}_{\mathrm{i}} \backslash \mathrm{H}_{1}\right)$ and $\mathrm{P}\left(\mathrm{e}_{\mathrm{i}} \backslash \mathrm{H}_{1} \mathrm{c}\right)$ was done by using the performance of each element $d_{i}$ within the defined set $D$, the values obtained for each event $\mathrm{e}_{1}-\mathrm{e}_{5}$ have the following ratio $\mathrm{P}\left(\mathrm{e}_{\mathrm{i}} \backslash \mathrm{H}_{1}\right)+\mathrm{P}\left(\mathrm{e}_{\mathrm{i}} \backslash \mathrm{H}^{\mathrm{c}}{ }_{1}\right)=1$. This ratio is true if and only if the calculation of these probabilities are performed, as in this case, on the fully defined sets. Generally, in most cases $\mathrm{P}\left(\mathrm{e}_{\mathrm{i}} \backslash \mathrm{H}_{1}\right)+\mathrm{P}\left(\mathrm{e}_{\mathrm{i}} \backslash \mathrm{H}^{\mathrm{c}}{ }_{1}\right) \neq 1$.

Based on the data presented in Table 1, using the equations of gradual introduction of the estimated influential events $\mathrm{e}_{1}-\mathrm{e}_{5}$ on the a priori probability $\mathrm{P}\left(\mathrm{H}_{1}\right)$, the adjusted values of initial a priori probability were obtained. In this case, in each successive step the previously calculated adjusted probability becomes the a priori probability for the next step. By using equations (10.1. $10.5)$ with gradual introduction of events $e_{1}-$ $\mathrm{e}_{5}$, final a posteriori probabilities for the considered set D or SP-EM, Table 2.

By the introduction of the certain events ei in the equations (10.1) to (10.5), for calculating the Bayesian a posteriori probability, an update of the "belief" in the truthfulness of the hypothesis $\mathrm{H}_{1}$ is being performed, in the light of observations and evidence that add new information to the initial or a priori estimate. With Bayesian updating of the sequential review of a posteriori probability, which is calculated in the equations (10.1) using equation (10.2) to (10.5), results were obtained which explain the observations defined by the new evidence nodes $\mathrm{e}_{2}-\mathrm{e}_{5}$.

Obtained results in the case of the set D or SP-EM, show that a priori probability $\mathrm{P}\left(\mathrm{H}_{1-\mathrm{D}}\right)$ increases with each addition of a new evidence node $\mathrm{e}_{1}$ to $\mathrm{e}_{5}$, where, after the introduction of all of the evidence nodes in equations (10.1) to (10.5), the a posteriori probability for the realization of the hypothesis $\mathrm{P}\left(\mathrm{H}_{1-\mathrm{D}}\right)$ obtains a value of $99.40 \%$, meaning that the SP-EM will become a part of the IUB with a probability of $99.40 \%$. Impact of events $\mathrm{e}_{1}-\mathrm{e}_{5}$ on the value of the a posteriori probabilitiy $\mathrm{P}(\mathrm{H1-D})$, is shown schematically in Figure 3.

With the possibility that a few minor errors were made in the estimates given in

Table 1. The estimated values for $P\left(e_{i} \mid H_{1}\right)$ and $P\left(e_{i} \mid H_{1}^{c}\right)$ for the events $e_{1}-e_{5}$ in the set $D$

\begin{tabular}{lccccc}
\hline \multicolumn{1}{c}{$\mathrm{e}_{\mathrm{i}}$} & $\mathrm{e}_{1}$ & $\mathrm{e}_{2}$ & $\mathrm{e}_{3}$ & $\mathrm{e}_{4}$ & $\mathrm{e}_{5}$ \\
$\mathrm{Pi}$ & & & & & \\
\hline $\mathrm{P}\left(\mathrm{e}_{\mathrm{i}} \backslash \mathrm{H}_{1-\mathrm{D}}\right)$ & 0.689 & 0.889 & 0.587 & 0.650 & 0.650 \\
$\mathrm{P}\left(\mathrm{e}_{\mathrm{i}} \backslash \mathrm{H}^{\mathrm{c}}{ }_{1-\mathrm{D}}\right)$ & 0.310 & 0.111 & 0.413 & 0.350 & 0.350 \\
\hline Note: $\mathrm{D}=\mathrm{EM}$ & & & & &
\end{tabular}

Table 2. The calculated values of the a posteriori probability for the set $D$

\begin{tabular}{cccccc}
\hline $\begin{array}{l}\mathrm{P}\left(\mathrm{H}_{1} \backslash \mathrm{e}_{\mathrm{i}}\right) \\
\mathrm{P}\left(\mathrm{H}_{1}\right)\end{array}$ & $\mathrm{P}\left(\mathrm{H}_{1} \backslash \mathrm{e}_{1}\right)$ & $\mathrm{P}\left(\mathrm{H}_{1} \backslash \mathrm{e}_{1}, \mathrm{e}_{2}\right)$ & $\mathrm{P}\left(\mathrm{H}_{1} \backslash \mathrm{e}_{1}, \mathrm{e}_{2}, \mathrm{e}_{3}\right)$ & $\mathrm{P}\left(\mathrm{H}_{1} \backslash \mathrm{e}_{1}, \mathrm{e}_{2}, \mathrm{e}_{3}, \mathrm{e}_{4}\right)$ & $\mathrm{P}\left(\mathrm{H}_{1} \backslash \mathrm{e}_{1}, \mathrm{e}_{2}, \mathrm{e}_{3}, \mathrm{e}_{4}, \mathrm{e}_{5}\right)$ \\
\hline $\mathrm{P}\left(\mathrm{H}_{1-\mathrm{D}}\right)$ & 0.689 & 0.947 & 0.963 & 0.984 & 0.994 \\
\hline
\end{tabular}




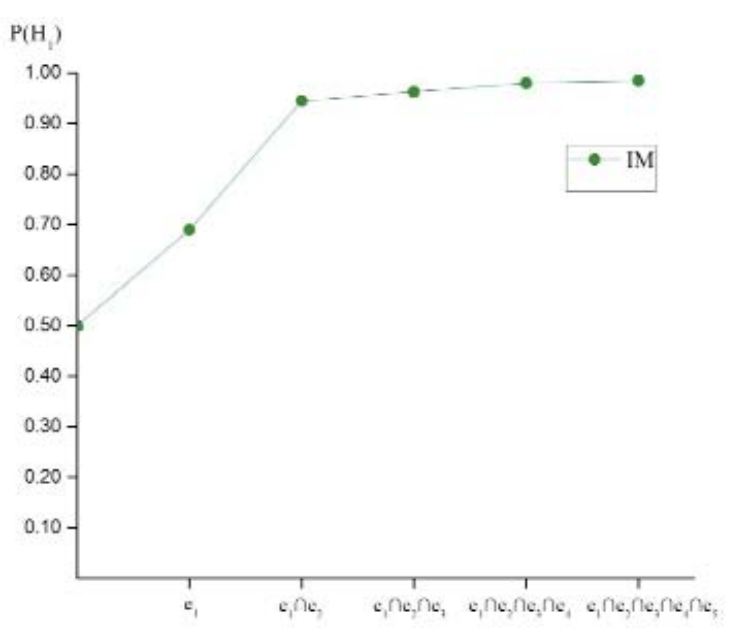

Figure 3. Impact of the events $e_{1}-e_{5}$ on the values for a posteriori probabilitiey $P\left(H_{1-D}\right)$

Table 1, within the limits of $\pm 10 \%$, the objective fact is that the given probability of SP-EM entering the IUB is very high. In the EM study program the largest number of professors and associates publish in the journals with IF, new scientific areas are continuously being conquered and implemented in the teaching process at all levels of study and in scientific publications. It has the fastest advancement rate in acquiring of new academic titles. It shows the biggest commitment to students and the highest transparency over the SPs' web site, which is one of the most visited in Southeastern Europe. The greatest interest among students is shown for this particular study program which has the largest index of graduate employment (over $90 \%$ of graduates were employed in relatively short period of time, under the conditions were it was very difficult to find employment), and furthermore over $95 \%$ of the classes is covered by verified academic literature, authored by professors who teach those classes. This SP is one of the few SP's in Serbia, which developed a wide network of alumni consisting of over $50 \%$ of graduates, where international cooperation has been achieved in the wider region, through a dozen summer schools for teaching assistants and graduate students each year and where it is a common practice for its professors to visit other universities. Image of the SP is created throughout the organization of two international conferences and by publishing a journal of international importance. In addition to these facts goes repeated accreditation for all three levels of study, where the reasoning of the decision in level III study states that this program is the "vanguard of developing and upgrading the quality of doctoral dissertation" in Serbia.

\section{CONCLUSION}

The derived model of Bayesian conditional probability for evaluating the position of SP-EM in the framework of IU has a general character and can be applied to risk assessment of any SP or a set of SP's. It is of particular importance to SP's within the non-integrated universities which aspire to become a part of an IU, with the aim to define the actions that would increase the probability of achieving the desired hypothesis $\mathrm{H}_{1}$ - entering of the $\mathrm{SP}$ in the IU, especially if the IU has a well-ranked position in the top 500 .

Position of the SP-EM is very good, with a high probability of remaining in the IUB. In order to maintain and promote this position, it is necessary to ensure the commitment of a greater number the SPs' members (elements of the set D) to the activities within the mentioned evidence nodes $\mathrm{e}_{1}-\mathrm{e}_{5}$, primarily throughout the activities of the SP's leadership, as well as to the new activities that occur as an imperative of the modern IU. 


\title{
"ВАУЕS"-ОВ МОДЕЛ ПРОЦЕНЕ РИЗИКА ПОЗИЦИЈЕ СТУДИЈСКОГ ПРОГРАМА У ИНТЕГРИСАНОМ УНИВЕРЗИТЕТУ - СТУДИЈА СЛУЧАЈА: ИНЖЕЊЕРСКИ МЕНАЏМЕНТ НА ТЕХНИЧКОМ ФАКУЛТЕТУ У БОРУ
}

\author{
Марија Савић, Предраг Ђорђевић, Ђорђе Николић, Иван Михајловић и \\ Живан Живковић
}

\section{Извод}

У раду је представљена проблематика процене ризика позиционирања студијског програма (СП), као основног дела савременог Интегрисаног универзитета (ИУ). Модел прогнозе позиције СП у ИУ развијен је на основама Вауеs-ове теореме условне вероватноће. У предложеном моделу „а priori“ вероватноћа ажурира се претходним догађајима (доказним чворовима) ei, чијим дешавањем је условљена коначна ,, posteriori“ вероватноћа позиција СП у ИУ. Дефинисани модел развијен је на примеру СП - Инжењерски менаџмент (ИМ) у оквиру Техничког Факултета у Бору (ТФБ), у циљу процене ризика израчунавањем условне вероватноће његове позиције у будућем ИУ у Београду (ИУБ). Резултати показују да СП-ИМ, својом садашњом структуром и нивоом активности, са вероватноћом изнад $99 \%$, може да буде део ИУБ. Дефинисани модел има универзални карактер и може бити примењен за анализу „а posteriori““ вероватноће позиције било ког СП са променом броја и садржине доказних чворова ei.

Кључне речи: „Вауеs“, вероватноћа, модел, студијски програм, Интегрисани Универзитет

\section{References}

Anderson, R.D., \& Vastag, G. (2004). Causal modelling alternatives in operations research: Overview and application. European Journal of Operational Research, 156 (1), 92-109.

Bernardo, J.M., \& Smith, A.F.M. (2000). Bayesian Theory, Wiley, New York.

Chen, S.H., \& Pollino, C.A. (2012). Good practice in Bayesian network modeling. Environmental Modelling \& Software, 37, 134-145.

Cooper, P. (2007). Knowing your "Lemons": Quality Uncertainty in UK Higher Education. Quality in Higher Education, 13 (1), 19-29.

EU Directive, 2013/0081 (COD).

Florian, R.V. (2007). Irreproducibility of the results of the Shanghai academic ranking of world universities. Scientometrics, 72 (1), 25-32.

Garvey, R.P. (2009). Analytical methods for risk management. CRS Press, New York.

Huang, M.H. (2012). Opening the black box of QS World University Rankings. Research Evaluation, 21 (1), 71-78.

Jaynes, E.T. (2003). Probability Theory: The logic of Science. Cambridge University Press, Cambridge.

Kalina, J. (2014). On robust information extraction from high-dimensional data. Serbian Journal of Management, 9 (1), 131144.

Khan, M.N., \& Adil, M. (2013). Data analysis techniques in service quality literature: Essentials and Advanced. Serbian Journal of Management, 8 (1), 95-112. 
Maslow, A.H. (1943). A Theory of human motivation. Psychological Review, 50 (4), 370-396.

O'Hagan, A., \& West, M. (2010). The Handbook of Applied Bayesian Analysis. Oxford University Press, Oxford.

Ordonez Galan, C., Matias, J.M., Rivas, T., \& Bastante, F.G. (2009). Reforestation planning using Bayesian network. Environmental Modelling \& Software, 24, 1285-1292.

Sando, S., \& Ferenčak, M. (2012). Alumni indicator as a criterion for evaluating the Quality of Academic Institution. International Journal of Industrial Engineering and Management, 3 (2), 113119.

Shay, S.K., \& Bakar, K.S. (2012). A comparison of Bayesian models for daily ozone concentration levels. Statistical Methodology, 9, 144-157. 